UDC 657:658.012

DOI: https://doi.org/10.32840/2522-4263/2020-1-53

Sakhno Lyudmila

Candidate of Sciences (Economic), Associate Professor, Associate Professor of the Department of Accounting and Taxation Tavriya State Agrotechnological University named after Dmitry Motornogo

Сахно Л.А. кандидат еконолічних наук, доцент, доцент кафедри обліку і оподаткування Таврійського державного агротехнологічного університету ілені Длитра Моторного

\title{
ACCOUNTING AND AUDIT OF ENVIRONMENTAL ACTIVITIES
}

\section{ОБЛІк І АУДИТ ПРИРОДООХОРОННОї ДІЯЛЬНОСТІ}

\section{ANNOTATION}

The article summarizes the theoretical provisions and practical recommendations for improving the system of accounting and audit of environmental costs in the enterprises of agricultural production in the conditions of greening of social production. The concept of accounting and audit in the context of environmental activities is clarified. The main reasons for the need for accounting and audit of environmental activities in agricultural enterprises are formulated. Characterization of the costs of operating activities in the ADS for the possibility of isolation of environmental costs in them, with the purpose of reflecting in accounting and the possibility of analyzing the efficiency of their use is given. It is proposed to allocate an independent calculation article to reflect the cost of production of environmental costs. In order to integrate accounting and analytical support in the context of an environmental crisis, it is proposed to supplement the accounting system with appropriate accounts and subaccounts that would reflect this area of activity of the economic entity. The issues of clarification and development of conceptual approaches to disclosure of the nature of the environmental audit are considered, the necessary steps for improvement and the preconditions for the implementation and dissemination of the environmental audit are outlined.

Key words: ecological accounting, audit, environmental activity, costs, revenues, agricultural enterprises, prospects, cost item.

\section{АНОТАЦІЯ}

У статті узагальнено теоретичні положення та практичні рекомендації щодо вдосконалення системи обліку та аудиту екологічних витрат на підприємствах сільськогосподарського виробництва в умовах екологізації суспільного виробництва Уточнено поняття обліку та аудиту в контексті природоохоронної діяльності. Стан та проблеми, що виникають у процесі обліку, аудиту, аналізу такої діяльності функціонуючих сільськогосподарських підприємств, формують уявлення про провідні сфери розвитку бухгалтерського обліку та аудиту екологічної діяльності в Україні. Сформульовано основні причини необхідності впровадження обліку та аудиту природоохоронної діяльності в сільськогосподарських підприємствах. Досліджено актуальність впровадження екологічного обліку в сільськогосподарських підприємствах України. Виявлено взаємозв'язок функцій та завдань обліково-аналітичної системи в умовах екологічної кризи, а також виокремлено проблеми відображення екологічних витрат у бухгалтерському обліку операційної діяльності. Класифріковано витрати на операційну діяльність в АПВ із можливістю виділення в них екологічних витрат з метою відображення в бухгалтерському обліку та аналізу ефективності їх використання. У досліджені охарактеризовано статті калькулювання сільськогосподарської продукції з метою виокремлення поточних екологічних витрат. Пропонується виділити окрему статтю калькулювання, яка відображатиме витрати на виробництво екологічно чистої продукції. 3 метою інтеграції бухгалтерського та аналітичного забезпечення в умовах екологічної кризи пропонується доповнити облікову систему відповідними рахунками та субрахунками, які б відображали цю сферу діяльності суб'єкта господарювання. Запропоновано механізм адаптації організації бухгалтерського та аналітичного забезпечення екологічної діяльності до запитів управління конкурентоспроможністю сільськогосподарських підприємств. Розглядаються питання щодо розробки концептуальних підходів до розкриття природи екологічного аудиту, окреслено необхідні кроки для його вдосконалення та визначено передумови для впровадження і розповсюдження.

Ключові слова: екологічний облік, аудит, природоохоронна діяльність, витрати, доходи, аграрні підприємства, перспективи, стаття витрат.

\section{АННОТАЦИЯ}

В статье обобщены теоретические положения и практические рекомендации относительно совершенствования системы учета и аудита природоохранных затрат на предприятиях АПП в условиях экологизации общественного производства. Раскрыто понятие учета и аудита в контексте экологической деятельности. Сформулированы основные причины необходимости ведения бухгалтерского учета природоохранной деятельности в аграрных предприятиях. Приведена характеристика расходов операционной деятельности в АПП для дальнейшего выделения в них природоохранных затрат, с целью отражения в бухгалтерском учете и возможности осуществления анализа эффективности их использования. Предложено выделение самостоятельной калькуляционной статьи для отражения в себестоимости продукции экологических издержек. С целью интеграции учетно-аналитического обеспечения в условиях экологического кризиса, предложено дополнить систему бухгалтерского учета соответствующими счетами и субсчетами, которые отражали бы данное направление в деятельности экономического субъекта. Рассмотрены вопросы уточнения и разработки концептуальных подходов к раскрытию сущности экологического аудита, а также определень необходимые мероприятия для внедрения и распространения экологического аудита в аграрных предприятиях

Ключевые слова: экологический учет, аудит, природоохранная деятельность, расходы, доходы, аграрные предприятия, перспективы, статья расходов.

Formulation of the problem. In today's environment, the role of the processes of greening production is increasing, the implementation of which will solve specific environmental and economic problems at the enterprise level. Analysis and control over the completeness and effectiveness of environmental activities at the enterprise, 
as well as the various forms of environmental impact of the enterprise are impossible without meaningful environmental accounting and audit. In addition, the lack of complete information on the environmental management processes of economic entities creates a wide range of problems for different groups of users of environmental and economic information, increases the totality of social, industrial and financial risks.

Analysis of basic research and publications. In fundamental works of domestic scientists, in particular, Balatsky O. [1], Galushkina T. [2], Karagodov I. [3], Mishinino E. [4], Pakhomova N. [5], Sadekova A. [6], Shkarupa V. [7], Boyko O. [8], Zamuli I. [9], Kirsanova T. [10], Levchenko O. [11], problems related to common issues of accounting and auditing of environmental costs at the enterprise level were substantively investigated; scientific and methodological approaches to the formation of information systems on the state of the environment were proposed.

Highlighting previously unresolved parts of a common problem. In the conducted researches it has been identified that the existing system of information on environmental activity at domestic agricultural enterprises does not meet the modern requirements, questions of introduction of ecological audit, methodology of cost accounting, calculation of losses from environmental pollution remain beyond the limits of research.

Setting objectives. The purpose of the study is to develop the theoretical and methodological bases for the formation of environmental accounting and audit in the overall management system of agricultural enterprises. In accordance with the stated purpose, the following tasks are defined:

- to assess the main trends of development, as well as the economic nature, place and role of environmental accounting and audit in the environmental management system;

- to investigate the existing system of information support of management decisions in the sphere of nature management and environmental protection at agricultural enterprises for the purpose of its improvement;

- to implement a system of planning and accounting of environmental costs in agricultural enterprises;

- to determine the directions and scientific and methodological basis for the implementation of environmental audit elements in the management system of the agricultural enterprise.

Outline of the main research material. In the context of intensive reforming of all units of agricultural production, the issue of compliance with environmental security requirements in agro-industrial complex, ensuring the culture of production, processing and consumption of agricultural products, which in turn must become the main factors in the process of revitalizing the agricultural potential of the country, become particularly important. It is the orientation to the balanced development of agricultural enterprises that will create the necessary prerequisites for the rational use of natural, labor, technological, financial and other resources to ensure the process of social reproduction.

Exacerbation of the ecological situation, caused by excessive environmental load, forces enterprises to find appropriate ways to solve this problem. In a market economy, the success of enterprises is increasingly dependent on the environmental factors of their own activities. Due to increased pollution in recent years, the consumption of fresh water by the Zaporizhzhia region has decreased by $23.65 \%$. About $79 \%$ of the groundwater reserves of the Zaporizhzhia region do not meet the requirements of the State Sanitary Standards in terms of physicochemical parameters. The volume of wastewater discharges into water bodies in 2018 amounted to 873.3 million $\mathrm{m} 3,64.3$ million m3 of which was polluted.

The volume of discharged contaminated return water to the water bodies of the Zaporizhzhia region is $7.36 \%$ of the total discharge. This was the reason for the reduction of used water for irrigation by $51.88 \%$.

In 2018 compared to 2010, emissions from stationary sources in all sectors of economy continued to increase. The largest pollutants of the atmosphere were metallurgical enterprises.

The amount of revenues (from environmental tax and monetary penalties for environmental damage) to local funds of the Zaporizhzhia region in 2018 amounted to 323,407 million UAH. The current expenditures of enterprises for protection and rational use in 2018 increased by 171.8 million UAH.

One of the environmental policy instruments aimed at promoting compliance with environmental legislation at enterprises is the conduct of environmental audits and the establishment of environmental management systems, with subsequent certification to ISO 14001 standards. According to Art. 11 of the Law of Ukraine No.1862-IV «On Environmental Audit» dated June 24, 2004 environmental audit is carried out in the process of privatization of state-owned objects, another change of ownership, change of specific owners of objects, as well as for the needs of environmental insurance, in case of transfer state and communal property for long-term lease, concession, creation of joint ventures on the basis of such facilities, creation, operation and certification of environmental management systems, as well as economic and other activities.

A number of enterprises in the Zaporizhzhia region, recognizing the potential for significant environmental and economic benefits from the implementation of environmental management systems and more environmentally friendly production methods, have worked to create and certify environmental management systems at the enterprise. At some enterprises this work is only planned.

In general, all environmental protection measures are approved by environmental committees run by enterprises and can be carried out either 
by the enterprise's own forces or by third parties. Costs caused by the implementation of such measures are both productive and economic in nature and are part of the costs of the enterprise.

Environmental expenditures are reflected in value in the aggregate of all types of resources required for environmental activities [4, p. 48].

The allocation of environmental costs to the cost of production must be made not in proportion to the sum of the basic costs of production, as is currently the case, but in proportion to the economic loss from the production of one or another product. This distribution of environmental costs is, in our view, more economically correct, because, first, the cost of production will directly reflect the costs associated with its production, and secondly, it will stimulate producers to take environmental measures.

Allocation of an independent calculation article requires drawing up a planned estimate of the corresponding costs.

The imperfection of methods of accounting for the costs of environmental activities significantly complicates or even makes it impossible to control them. The planning and rationing of environmental expenditures are not at the best stage. Regulatory documents in agriculture do not provide for the allocation of environmental costs in a separate item of costing. In addition, there is no ambiguity in the classification of the above costs to certain articles.

Thus, the costs of maintenance of environmental protection structures and devices (wages and deductions for social activities of workers engaged in the maintenance of structures and devices, auxiliary materials, depreciation of treatment facilities) are planned in the cost estimates for current and major repairs, and the cost of outsourcing services substances and solutions, measurements of emissions into the atmosphere, as well as the amount of charges for environmental pollution as part of the cost estimate for occupational safety and health.

Such heterogeneity of the methodology of planning expenditures for environmental measures leads not only to the incomparability of the regulatory framework with the actual data, but also to the fact that part of the costs of environmental activities is not covered at all by the normalization [9, p. 7].

The shortcomings of the methodology of accounting and planning of environmental expenditures turn the formation of indicators of reporting on environmental charges and current costs of nature conservation into a rather time-consuming procedure that requires additional calculations and decryption. Even the decryption in the current situation is not appropriate, since the accuracy of the current cost data will be rather doubtful, since, as noted above, they are scattered in the total cost of maintenance and operation of machinery and equipment, workshop and administrative costs.
Therefore, in view of the above, we consider it necessary to take the following steps to improve the accounting, reporting and audit of environmental spending.

Firstly, in order to control environmental spending, it is advisable to introduce a special article, "Environmental Costs", in the standard nomenclature of costing articles. In this case, the principle of allocating a separate item of costing will not be based on the principle of cost share, which it characterizes in the cost of production, but the principle of the need to increase control over individual costs. This approach eliminates the problem of planning environmental expenditures, will allow to estimate these costs, to use the allocated amounts of expenditures solely for the purpose, and will help to improve their distribution between types of products.

If for some reason businesses find it inappropriate to introduce a special costing item, then the current environmental costs may be collected in a separate item as part of the overhead costs.

Allocating a special item of costing or a separate item to the overhead costs eliminates the problem of dispersion of environmental expenditures in the cost estimates of other costs and will give them their own status, rather than a component of labor costs.

The nomenclature of the items of expenditure to be accounted for may differ by industry and type of environmental activity, but the main ones will be:

- materials, low value items and wearables;

- the basic wages of production workers;

- additional wages of production workers;

- contributions to social needs;

- fuel and energy for technological needs;

- total expenditures.

Considering the sufficiently high proportion of the cost of services provided by third-party organizations for environmental measures, it is advisable to allocate them to a separate article in the total amount of environmental protection costs.

When drawing up the cost estimates for environmental activities, it should be taken into account that they have a complex nature, that is, there are variables that change in proportion to the change in production among the environmental costs (materials used to neutralize harmful substances), conditionally constant, the value of which varies slightly relative to production volumes and fixed ones, the size of which does not change with respect to changes in production volumes (maintenance of water neutralization stations).

Forming cost estimates for the whole enterprise in terms of economic elements, it is advisable to allocate the costs of environmental activities «including» such elements as «Auxiliary materials», «Energy for technological needs», "Depreciation of fixed assets», which will allow in-depth analysis of environmental protection activities and determine cost directions.

Secondly, it is advisable to reflect them on the special account "Expenditures of environmental 
activity" for the formation of accounting data on the costs of environmental protection activities, the necessity of which has been repeatedly mentioned in the economic literature [10, p. 32].

Of course, the implementation of this proposal will slightly increase the volume of accounting work at the enterprise, but will significantly reduce the complexity of obtaining information on environmental costs, since there is no need for such painstaking and time-consuming work as sampling and regrouping primary and analytical accounting data. In addition, the information thus obtained does not differ in the accuracy and reliability inherent in system accounting information.

The account «Costs of environmental protection" in some enterprises can be used as a collection and distribution, and as a cost in others.

The first option is offered to those enterprises where the environmental protection activities are insignificant, it is not structurally separated and environmental services are not provided to outside organizations. Most agricultural enterprises of Melitopol district belong to them. In this case, a separate account will allow to control the planned cost estimate and accumulate information about the total amount of environmental costs to reflect them in the accounts and more accurate distribution between the types of products produced than it is possible under the existing system of accounting for environmental costs (or more precisely, for its absence).

In our opinion, it would be advisable to assign the code 913 to the cost of environmental protection, since environmental costs are, first of all, unlikely to be directly attributable to the cost of specific products, that is, they require a certain allocation base; secondly, they are complex in nature; and, finally, thirdly, they have generic characteristics by nature, that is, indirectly related to the manufacturing of products.

In the case of enterprises with significant environmental activities (for example, where current environmental costs exceed $0.5 \%$ of the cost of production), which have specialized workshops and provide environmental services to other enterprises, the expense of environmental protection activities should have a calculating nature (e.g. sub-account 237) and serve to determine the cost of environmental services and to determine optimal prices for services provided to third parties, as well as to determine the financial result of e environmental protection activities. The scheme of cost accounting for environmental activities is presented in Fig. 1.

Analytical accounting can be carried out by structural subdivisions of the nature protection complex as centers of responsibility (by specialized shops and subdivisions), by specific directions of nature protection activity with differentiation by cost centers and by cost items [11, c. 12].

Expenditures that are accounted for in the cost of environmental protection activities are credited to the accounts of the main or ancillary production (wastewater treatment, etc.), and the cost of services to third-party organizations is credited to the cost of implementation. Moreover, the account «Expenditure on environmental protection activities" can form a debit balance in the presence of work in progress (for example, sewage treatment can be gradual and continuous).

Thirdly, the separation of environmental costs is necessary to solve the problems of ordering their distribution between different types of products or operations. Today, environmental

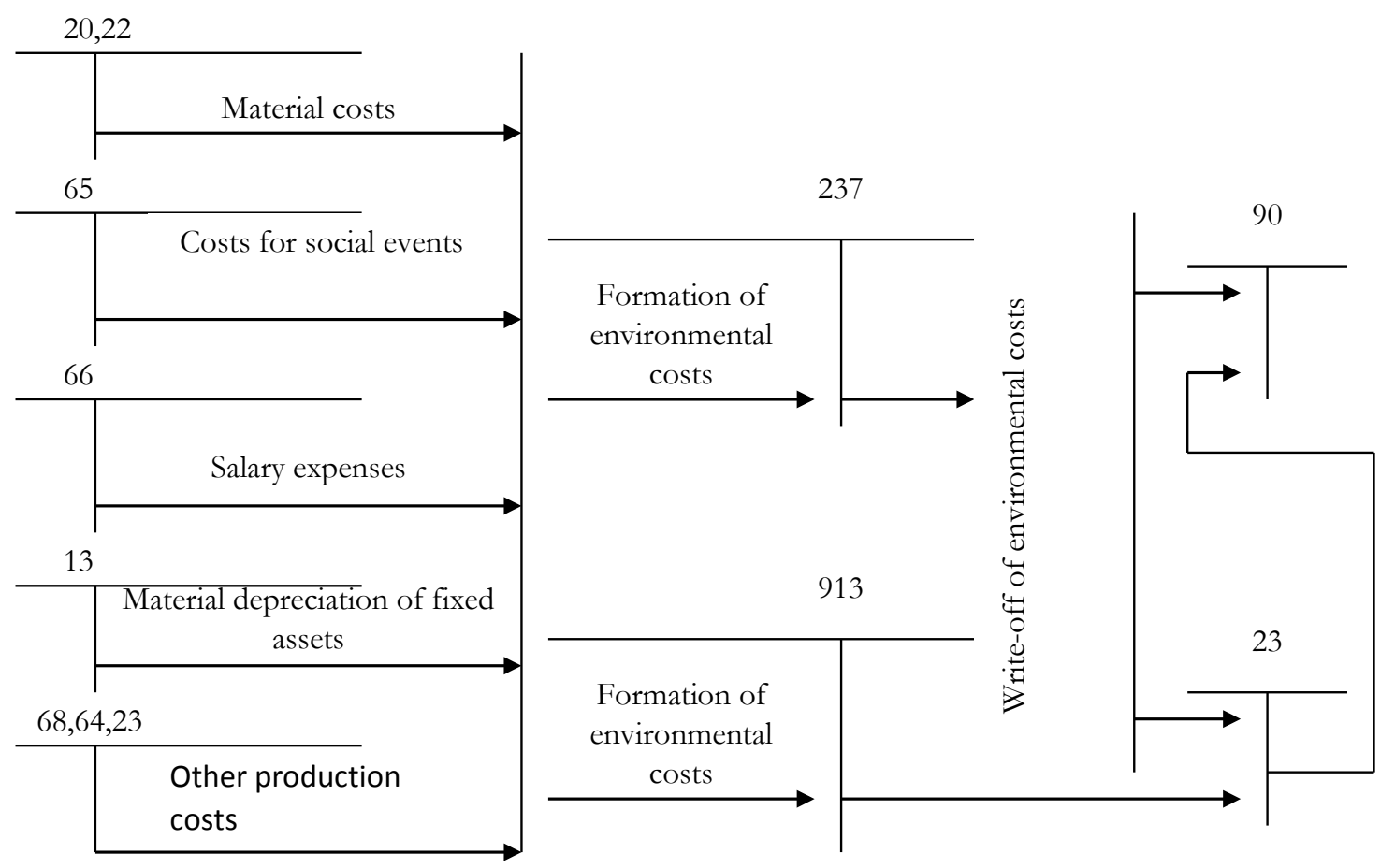

Fig. 1. Scheme of cost accounting for environmental activities using sub-accounts 237 and 913 
costs are shared with those costs that they are accounted for. Accordingly, in most cases, the allocation base has no economically justified link to these costs. Thus, much of the environmental costs, which are concentrated in the overhead of production costs, are distributed according to the average percentage of the wages of production workers, and the costs of environmental activities, concentrated in administrative costs, are written off in the period of their occurrence on the financial result. However, environmental costs depend on the volume, toxicity and complexity of disposal of the waste generated in the manufacture of certain products, and not on the complexity of the latter. As a result, costs are completely distorted, which has a negative impact on pricing. In addition, identifying the most "environmentally friendly" products could be a signal to revise the design or technology of their manufacture.

Conclusions. In the article, the principles of improvement of management of flows of ecological information in the structure of the enterprise are developed, directions of improvement of the systems of ecological accounting and audit are formulated within the framework of the analysis of the accounting and audit system in agricultural enterprises.

Recommendations are proposed that are to allocate a separate costing item to reflect the cost of environmental protection products, as well as a separate synthetic account, to account for these costs, which will allow you to plan the current costs of environmental activities, depending on the allocated volume of costs and use them clearly purposefully, and will help improve their distribution between products.

Proposals for improving the information management system for environmental management will create conditions for "comparison in rights" of basic, economic and environmental activities in their evaluation and promotion; will provide a solution to the problem of determining the economic effectiveness of environmental measures and assessing the economic losses of society due to pollution of the environment.

With regard to environmental audit, it is advisable for agricultural enterprises to conduct it when it is necessary to:

- determine the compliance of the enterprise with the requirements of environmental legislation;

- avoid excessive environmental charges and penalties;

- find out the availability of reserves of raw materials and energy resources at the enterprise;

- increase the investment attractiveness of the enterprise;

- formulate the enterprise's environmental strategy and policy;

- increase the competitiveness of the enterprise and increase consumer loyalty through the production of products that meet all environmental and hygiene requirements;
- to reach the international level and to strengthen the position of the company among foreign partners;

- to certify the enterprise environmental management system to ISO 14001 standard.

In order to find ways to reduce the cost of environmental payments, an enterprise may periodically carry out specialized audits of payments for the use of natural resources: for land, water use, waste management, energy use, etc. within the functional limits of its recommendation.

\section{REFERENCES}

1. Balatskyi, O., Lukyanikhin, V., Lukyanikhina, E. (2000), Ekologicheskiy menedzhment: problemy i perspektivy stanovleniya i razvitiya [Environmental management: problems and prospects of the formation and development]. Economy of Ukraine, no 5, pp. 68-73. (in Russian)

2. Halushkina, T.P., Kharichkov, S.K. (1998), Ekologicheskiy menedzhment $\vee$ Ukraine: realii perspektivy [Environmental management in Ukraine: realities of prospects]. Institute of market problems and economic and ecological researches of NAS Ukraine, Odessa, Ukraine, 107 p. (in Russian)

3. Karahodov, I. (1998), Ekologicheskiy menedzhment prirodopol'zovaniya [Environmental management of nature use]. Business-Inform, no 19, pp. 3-7. (in Russian)

4. Mishenin, Ye.V., Semenchenko, B.A., Mishenina, N.V. (1996) Ekonomicheskiy mekhanizm ekologizatsiya proizvodstva [The economic mechanism for ecologization of production]. Sumy, Ukraine: IPP «Mríya» -1"-LTD, 140 p. (in Russian)

5. Pakhomova, N.V., Rikhter, K.K. (1999), Ekonomika prirodopolzovaniya i ekologicheskiy menedzhment [Environmental Economics and Environmental Management], textbook. St.-Peterburg University, PITER, Russia, 488 p. (in Russian)

6. Sadekov, A.A. (2004), Mekhanizmy ekologo-ekonomicheskogo upravleniya predpriyatiyami [Mechanisms of ecological and economic management of the enterprises], monograph. Kharkiv, Ukraine, «INZHEK», 224 p. (in Russian)

7. Shkarupa, V.F. (2002), Osnovy ekolohii ta bezpeky tovariv narodnoho spozhyvannia [Fundamentals of ecology and safety commodities for public consumption], textbook. Kyiv, Ukraine, KNTEU, 217 p. (in Ukrainian)

8. Boiko, O.Yu. (2001), Ekoloho-ekonomichni aspekty upravlinnya korporatsiyamy [Ecological and economic aspects for corporation management]. Naukovyi visnyk ahrarnoi nauky Prychornomoria Mykolaivskoi derzhavnoi ahrarnoi akademii, Special Issue 3(12) in two volumes. Vol. 1, pp. 108-111. (in Ukrainian)

9. Zamula I.V. (2005), Oblik i kontrol' operatsiy z okhorony navkolyshn'oho seredovyshcha [Accounting and control of operations on environmental protection]. Accounting and Finance of AIC, no 2, pp. 4-8. (in Ukrainian)

10. Kirsanova T.A. (2003), Informatsionnoye obespecheniye upravlencheskogo ucheta ekologicheskikh zatrat [Information support for management accounting of environmental costs], textbook. Sumy, Ukraine: «Kozatsky Val», 52 p. (in Russian)

11. Levchenko O.P. (2009) Zahal'na kharakterystyka metodychnykh pidkhodiv shchodo formuvannya vytrat u sil'skohospodars'kykh pidpryyemstvakh [General characteristics of methodological approaches to cost formation in agricultural enterprises]. Ahrosvit, no 24/12, pp. 10-13. (in Ukrainian) 


\section{БІБЛІОГРАФІЧНИЙ СПИСОК:}

1. Балацкий О. Экологический менеджмент: проблемы и перспективы становления и развития. Экономика Украины. 2000. № 5. С. $68-73$.

2. Галушкина Т.П. Экологический менеджмент в Украине: реалии перспективы. Одеса: Інститут проблем рынка и экономико-экологических исследований НАН Украины, 1998. $107 \mathrm{c}$.

3. Карагодов И. Экологический менеджмент природопользования. Бизнесинформ. 1998. № 19. С. 3-7.

4. Мишенин Е.В. Экономический механизм экологизация производства. Сумы : ИПП «Мрія»-1”-ЛТД, 1996. 140 с.

5. Пахомова Н.В. Экономика природопользования и экологический менеджмент: учебник. Санкт Петербург : Из-во С.-Петербургского университета, 1999. $488 \mathrm{c}$.
6. Садеков А.А. Механизмы эколого-экономического управления предприятиями : монография. Харков : Изд. дом «ИНЖЕК», 2004. 224 c.

7. Шкарупа В.Ф. Основи екології та безпеки товарів народного споживання: підручник. Київ : КНТЕУ, 2002. 217 с.

8. Бойко О.Ю. Еколого-економічні аспекти управління корпораціями. Науковий вісник аграрної науки Причорномор'я Миколаївської державної аграрної академії. Спец. випуск 3(12) в 2-х т. Т. 1. Миколаїв, 2001. С. 108-111.

9. Замула І.В. Облік і контроль операцій з охорони навколишнього середовища. Облік і фрінанси АПК. 2005. № 2. С. 4-8.

10. Кирсанова Т.А. Информационное обеспечение управленческого учета экологических затрат. Сумы : Изд-во «Козацький вал», 2003. 52 с.

11. Левченко О.П. Загальна характеристика методичних підходів щодо фрормування витрат у сільскогосподарських підприємствах. Агросвіт, № 24/12, 2009, с. 10-13. 